\title{
Tapping Into the Sun
}

Today's Applications of Photovoltaic Technology

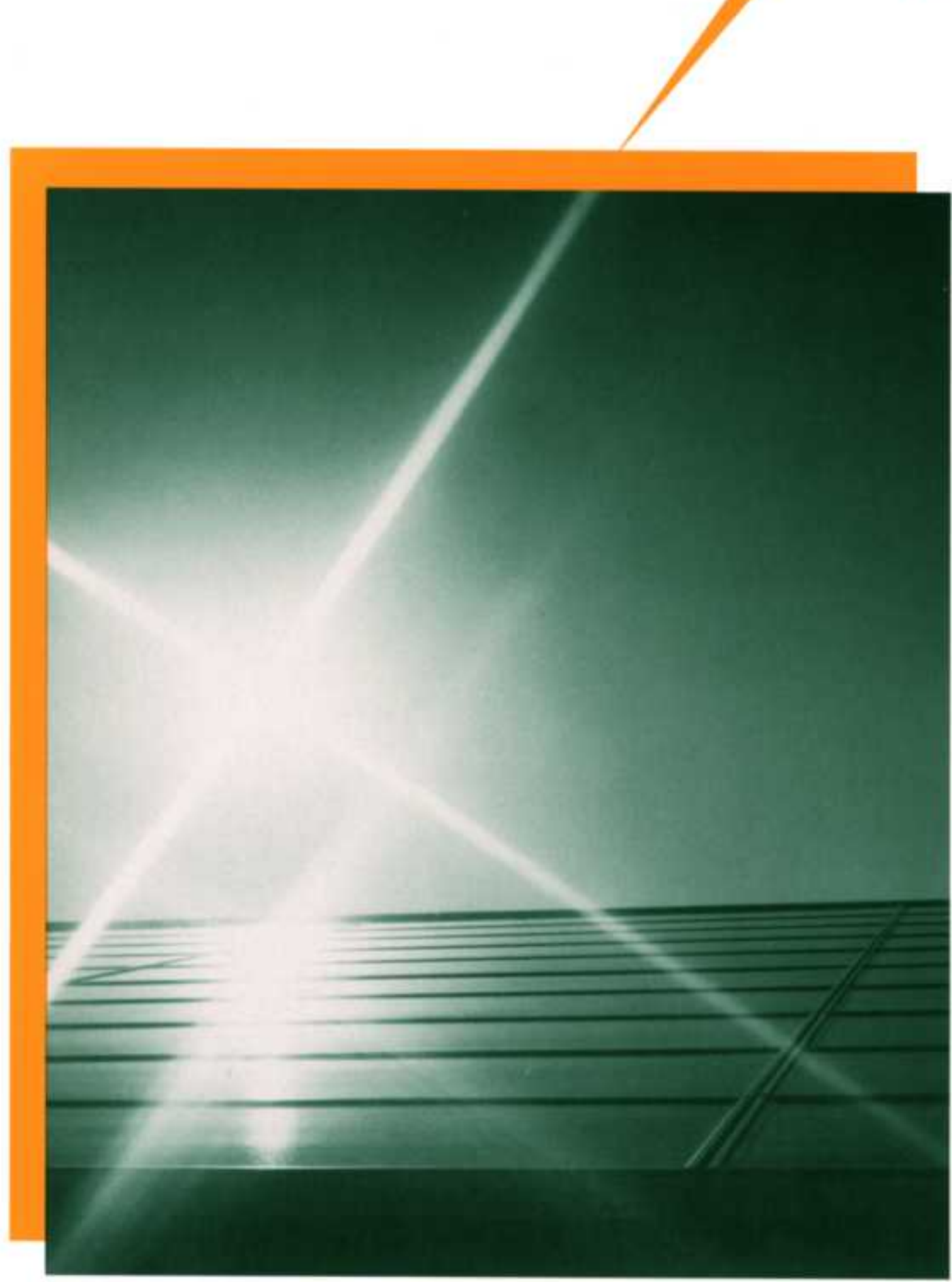




\section{Preface}

olar electric systems are no longer exotic or experimental to those who work with them. Many people, however, have basic questions about how solar electric systems, also called photovoltaics or PV, can meet their energy needs.

To answer these questions, this brochure describes a few of the many ways PV is working today. From the simplest systems used to power pumps and fans to the complex systems used by utilities to expand generation capacity, we describe actual projects, explain how they work, and discuss why their operators chose PV to supply electricity.

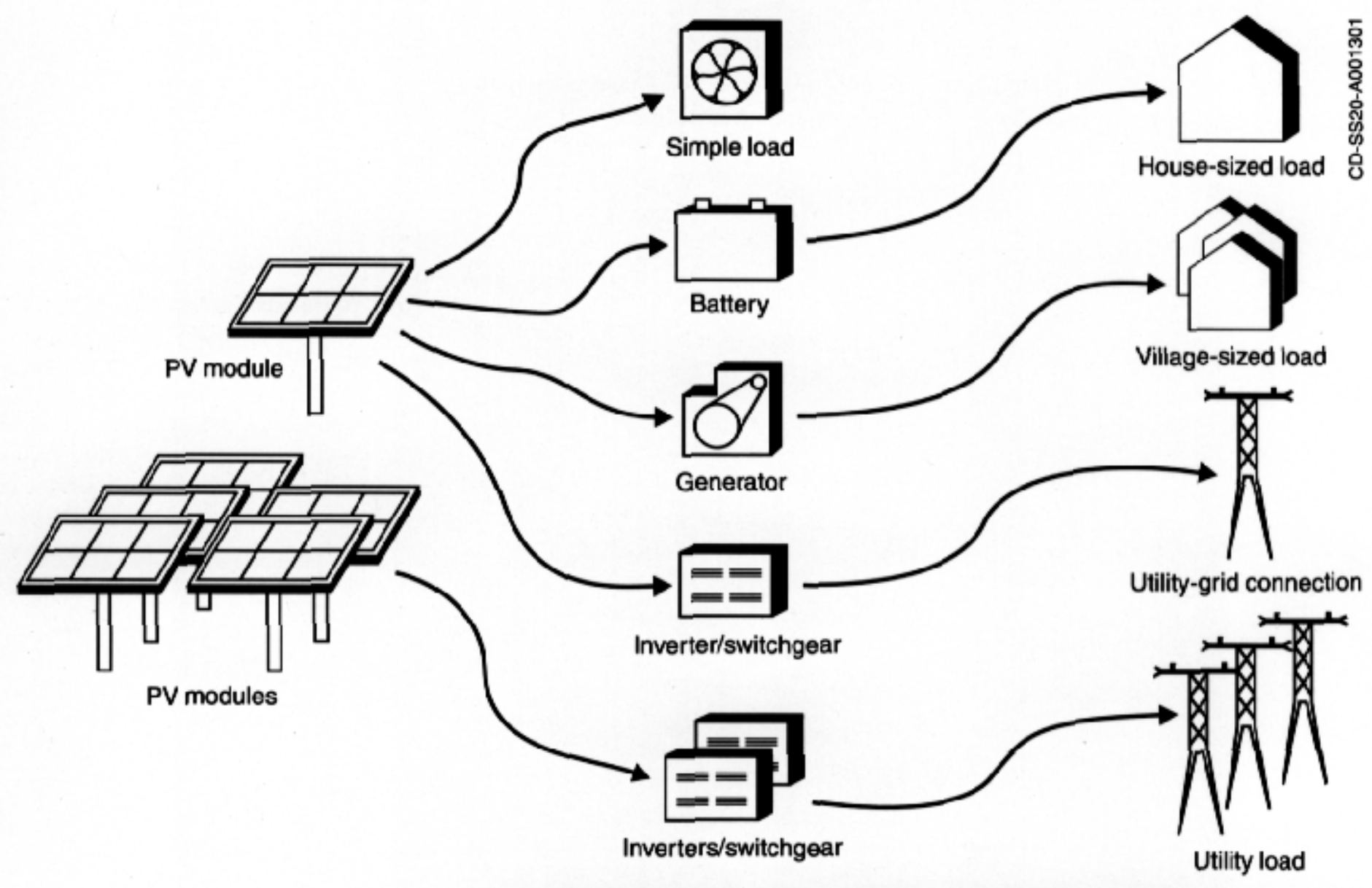

When sunitght strikes the surface of PV modules a flow of electricity is generated. Wires collect this electricity and guide it to the equipment to be powered-loads - or to batteries for storage. Controllers keep batteries from overcharging or nunning too low. Inverters convert direct current (dc) electricity coming from PV modules and batteries to alternating current (ac). Sometimes backup generators are added to PV systems to help power the load. Ac power from additional generators passes through roctifiers if it is usod to charge batteries. PV systems connected to the utility line feed power through inverters and switchgear out to other utility customers. 


\section{Contents}

\section{Electricity from the Sun}

Solar cells convert sunlight directly into electricity—our most versatile form of energy.

\section{$4 \quad$ Simple PV Systems}

The sunlight that creates the need for water and ventilation can be harnessed using the most basic PV systems to meet those same needs.

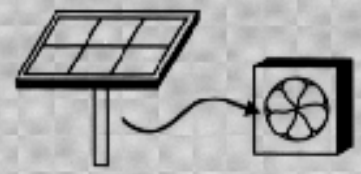

\section{$7 \quad$ PV with Batteries}

Storing electrical energy in batteries makes PV systems a reliable source of electric power, day or night, rain or shine.

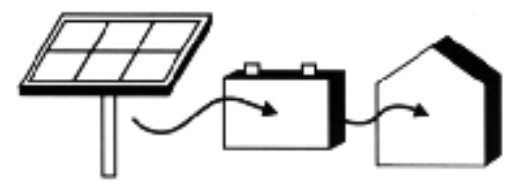

\section{PV with Generators}

When power must always be available, or when larger amounts of electricity than a PV system alone can supply are needed, an electric generator can work effectively with a PV system to supply the load.

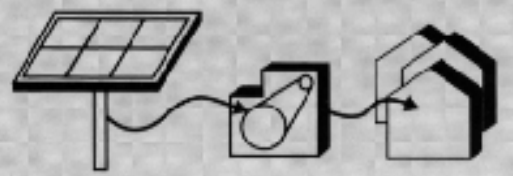

\section{Grid-Connected PV}

A grid-connected PV system can use the utility in place of batteries.

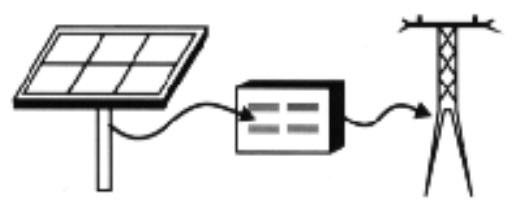

18 Utility-Scale PV

Utilities are exploring PV to expand generation capacity and meet increasing environmental and safety concerns.

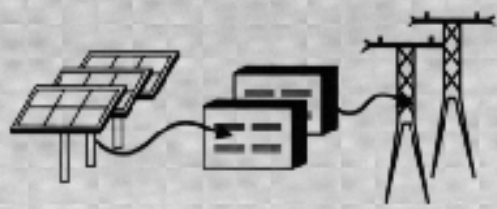

\section{Electricity Now and in the Future}

As PV technology continues to improve, it steadily moves into new and larger markets.

\section{For More Information}


PV research and development, supported by the U.S. Department of Energy (DOE), private industry, and universities, has improved the performance and substantially reduced the cost of PV. Researchers continue to experiment with various combinations of materials to increase the amount of electricity generated and reduce the cost of manufacturing.

The U.S. industrial partners in this PV research and development have built a domestic energy industry with sales totaling about \$135 million in 1992. (U.S. companies account for about $37 \%$ of the worldwide market for PV.) About two-thirds of this production is exported. Both domestic and international market analysts, meanwhile, predict substantial growth for U.S.-manufactured $\mathrm{PV}$ products in the future.

\section{PV Has Advantages}

PV offers advantages over diesel generators, primary (one-time use) batteries, and conventional utility power.

- High Reliability. PV cells were originally developed for use in space, where repair is extremely expensive, if not impossible. PV still powers nearly every satellite circling the earth because it operates reliably for long periods of time with virtually no maintenance.

- Low Operating Costs. PV cells use the energy from sunlight to produce electricity - the fuel is free. With no moving parts, the cells require little upkeep. These low-maintenance, cost-effective PV systems are ideal for supplying power to communication stations on mountain tops, navigational buoys at sea, or homes far from utility power lines.

- Non-polluting. Because they burn no fuel and have no moving parts, PV systems are clean and silent. This is especially important where the main alternatives for obtaining power and light are from diesel generators and kerosene lanterns.

- Modular. A PV system can be constructed to any size. Furthermore, the owner of a PV system can enlarge or move it if his or her energy needs change. For instance, homeowners can add modules every few years as their energy usage and financial resources grow. Ranchers can use mobile trailer-mounted pumping systems to water cattle as they are rotated between fields.

- Low Construction Costs. PV systems are usually placed close to where the electricity is used, meaning much shorter wire runs than if power is brought in from the utility grid. In addition, using PV eliminates the need for a step-down transformer from the utility line. Fewer wires mean lower costs, shorter construction time, and reduced permitting paperwork, particularly in urban areas. 
Olizer Romey chose PV power to pump water to his drought-stricken ranch in South Dakota.

Tn the "gumbo" soil country of South Dakota there 1 is not much water underground, so when rancher Oliver Romey's stock dams went dry in 1990 he had a hard time finding a new source of water. When he found water on his land, the well was 2.4 kilometers $(\mathrm{km})$ (1.5 miles [mi]) from the power line. Extending the line to power his pump would have cost $\$ 18,000$. So, like many people in the area, Romey hauled water to his cattle in tank trucks each day. After two seasons of hauling water, he read about solar-powered pumping provided by the Northwest Rural Public Power District.

The Northwest Rural Public Power District, along with many utilities around the country, offers customers the choice of running new power lines or installing a PV system. PV water pumping is particularly popular in rural areas because, although the electricity is used as it is generated, the water can be stored in tanks and reservoirs. (Storing water is much cheaper than storing electricity:)

Romey chose PV, and the utility installed 20 PV modules designed to work with the dc pump and pipeline size Romey required. He now pays the utility a monthly fee, which covers the system's installation, insurance, maintenance, and a return on the utility's investment.

The PV system pumps water through his $9 \mathrm{~km}(5.6 \mathrm{mi})$ of pipeline to four stock tanks that supply over 150 head of cattle. And with the new pipeline, he can graze cattle on two fields that he could not use before.

"For the first time in years, I don't have to worry about getting water to my cattle," Romey says. "I think this solar system is just as amazing as when the REA (Rural Electrification Administration) first brought electricity out to the ranch."

\section{Water for trees}

\section{The City of Littleton, in Colorado, chose PV to irrigate 1400 newly planted trees along the South Platte River.}

Tn 1992, Littleton launched an ambitious project to turn wasteland into 1 parkland along the South Platte River near Denver, Colorado. Naming the project " 10,000 Trees," the city planted 1400 native trees in former gravel mining areas along the river. But the city needed to water these saplings-set out along a $2.7-\mathrm{km}(1.7-\mathrm{mi})$ stretch of bike path-for several years to get them established. And the setting in this wildlife refuge had to stay as natural as possible.

Before choosing PV, the city considered three energy options for pumping water. It decided against a diesel or gasoline generator because they are too noisy and demand too much attention from park department personnel. It decided against expanding the utility power line because the city did not want

Twenty PV modules generate 1600 watts of dc electricity to power a centrifugal pump at this South Dakota ranch. The system pumps 114 liters a minute from a well 13 meters deep and sends it 9 kilometers through a pipeline to other pastures. If water needs increase, more modules can be added. (Photo: Rural Electric Nebraskan)
Are PV pumping

systems reliable?

Yes. A recent survey of more than 250 PV-powered pumping installations by EPRI

found PV to be a very reliable source of power for pumping systems. In fact, the PV modules are the most reliable parts of the systems; none of the systems in this study experienced module failures. The pumps experienced operational and maintenance problems common to all pumping systems. 


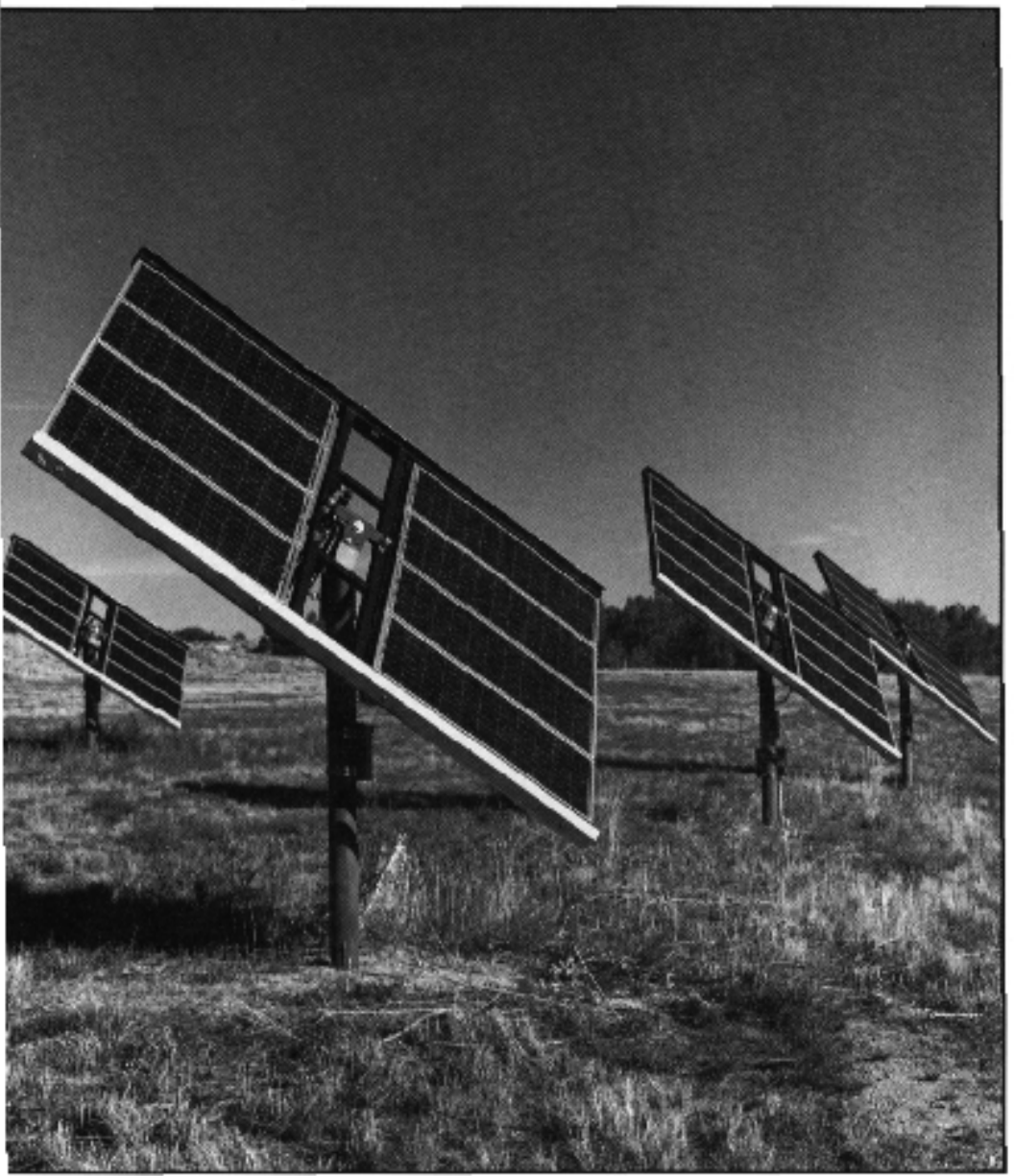

the expense or visual impact of power lines rumning over the park, and it only needed the power for a couple of years until the trees were established.

At the suggestion of the local utility, Public Service Company of Colorado, the city chose a PV-powered irrigation system. The system is quiet, requires no overhead wires, and can be moved to a new project once the trees are established. Although the PV system cost was greater than the cost of running wires to the utility line, its environmental advantages and portability made it more attractive to the city.

The PV system provides electricity during daylight hours to pump water from a small pond to water the trees. There is no need to store electricity or water, so the system is very simple - a dc motor and pump float on the pond. The five PV arrays are mounted on trackers that follow the sun during the day to increase electrical output.

"The townspeople are very pleased with how the solar panels look," says Littleton Mayor Susan Thornton. "The PV modules quietly do their job with no muss, no fuss, and no bother." In fact, the city is so pleased it has installed several smaller PV-powered park irrigation systems in other parts of Littleton.

This irnigation system, instaked in April 1992, pumps 114 lifers of water per minute during daylight hours - no storage is needed. The 2500 watts of PV-generated dc electricity powers two pumps, two controllers, and 43 solenoid valves that control water flow to 1400 native trees. (Photo: Warren Gretz, National Renewable Energy Laboratory)

\begin{tabular}{|c|c|c|c|c|c|c|c|c|}
\hline \multicolumn{9}{|c|}{ Applications of PV Systems Without Electrical Storage } \\
\hline 21 & $\begin{array}{l}\text { Homes/ } \\
\text { Famms/ } \\
\text { Ranches }\end{array}$ & $\begin{array}{l}\text { Commercial } \\
\text { Industrial }\end{array}$ & $\begin{array}{l}\text { Pubic } \\
\text { Services: } \\
\text { parks, rest } \\
\text { rooms, bus } \\
\text { shelters }\end{array}$ & $\begin{array}{l}\text { Transportation: } \\
\text { rail, highway. } \\
\text { bus, marine, } \\
\text { air }\end{array}$ & $\begin{array}{l}\text { Buildings: } \\
\text { offices, } \\
\text { schools, } \\
\text { apts }\end{array}$ & $\begin{array}{l}\text { Utilities: } \\
\text { electric, } \\
\text { gas, water }\end{array}$ & $\begin{array}{l}\text { Communication: } \\
\text { radio, TV, } \\
\text { telephone, } \\
\text { ham radio }\end{array}$ & $\begin{array}{l}\text { Rural } \\
\text { Communities: } \\
\text { domestic' } \\
\text { intemational }\end{array}$ \\
\hline $\begin{array}{l}\text { Pump water to } \\
\text { reservoir }\end{array}$ & $\bullet$ & $\bullet$ & $\bullet$ & & & $\bullet$ & & $\bullet$ \\
\hline $\begin{array}{l}\text { Pump water from } \\
\text { flooded fields }\end{array}$ & $\bullet$ & & $\bullet$ & & & & & $\bullet$ \\
\hline $\begin{array}{l}\text { Circulation pumps } \\
\text { for de-cing }\end{array}$ & $\bullet$ & & $\bullet$ & & & & & $\bullet$ \\
\hline Water punification & $\bullet$ & $\bullet$ & $\bullet$ & & & & & $\bullet$ \\
\hline Evaporative cooling & $\bullet$ & $\bullet$ & $\bullet$ & $\bullet$ & $\bullet$ & $\bullet$ & $\bullet$ & $\bullet$ \\
\hline Ventilation fans & $\bullet$ & $\bullet$ & $\bullet$ & $\bullet$ & $\bullet$ & $\bullet$ & $\bullet$ & $\bullet$ \\
\hline Aerate pond water & $\bullet$ & $\bullet$ & $\bullet$ & & & & & $\bullet$ \\
\hline
\end{tabular}




\section{PV with Batteries}

In the most remote and hostile environments, $P V$-generated electrical energy stored in batteries can power a wide variety of equipment.

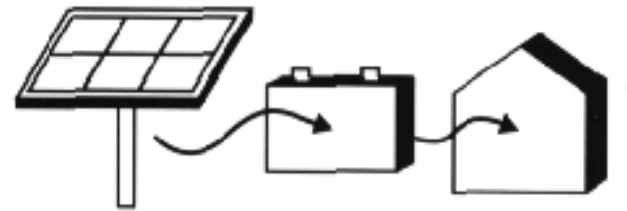

toring electrical energy makes PV systems a reliable source of electric power day and night, rain or shine. PV systems with battery storage are being used all over the world to power lights, sensors, recording equipment, switches, appliances, telephones, televisions, and even power tools.

PV systems with batteries can be designed to power dc or ac equipment. People who want to run conventional ac equipment add a power conditioning device called an inverter between the batteries and the load. Although a small amount of energy is lost in converting dc to ac, an inverter makes PV-generated electricity behave like utility power to operate everyday ac appliances, lights, and even computers.

PV systems with batteries operate by connecting the PV modules to a battery, and the battery, in turn, to the load. During daylight hours, the PV modules charge the battery. The battery supplies power to the load whenever needed. A simple electrical device called a charge controller keeps the batteries charged properly and helps prolong their life by protecting them from overcharging or from being completely drained.

Batteries make PV systems useful in more situations, but also require some maintenance. The batteries used in PV systems are often similar to car batteries, but are built somewhat differently to allow more of their stored energy to be used each day. (They are said to be "deep cycling," like the batteries used on golf carts.) Batteries designed for PV projects pose the same risks and demand the same caution in handling and storage as automotive batteries. The fluid in unsealed batteries should be checked periodically, and batteries should be protected from extremely cold weather.

A solar generating system with batteries supplies electricity when it is needed. How much electricity can be used after sunset or on cloudy days is determined by the output of the PV modules and the nature of the battery bank. Including more modules and batteries increases system cost, so energy usage is carefully studied to determine optimum system size. A well-designed system balances cost and convenience to meet the user's needs, and can be expanded if those needs change.

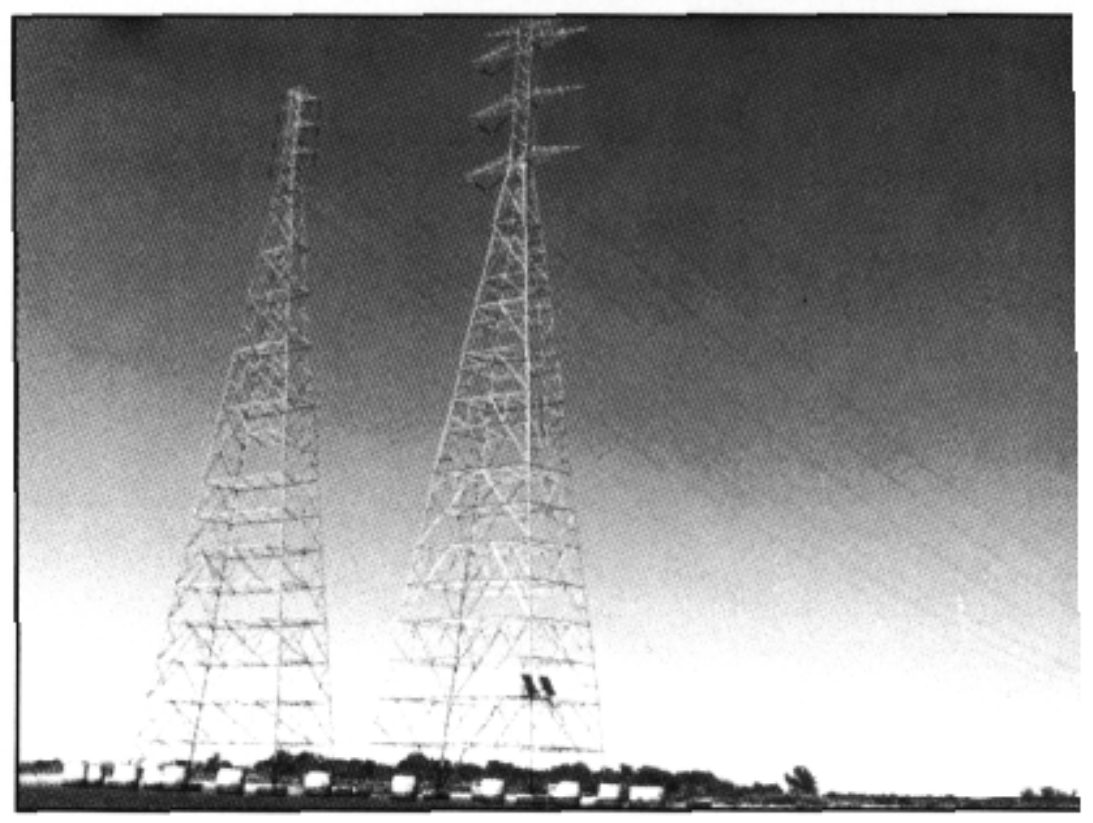

The Coast Guard has converted over 10,000 navigational aids (top) to be powered by photovoltaics since 1984. They have saved millions of doflars a year in maintenance, battery replacement, and battery disposal costs. (Photo: Northem Powor Systoms)

These utikty high-voltage lines (bottom) on 100-meter towers cross the Houston Ship Channel in Texas. Houston Power and Light chose PV to powor the aircraft waming beacons because it is less expensive than tapping into the power lines. (Photo: Northem Power Systems) 


\section{Can I get a tax credit for installing a PV system?}

That depends-some systems qualify and some don't. In 1993 a $10 \%$ federal investment tax credit was in effect for systems installed as business property. But this federal credit doesn't apply to residential systems. Furthermore, the laws in states and within special taxing districts vary across the country. Some states allow income tax deductions or credits for PV systems, and other states provide a sales tax exemption for the purchase price of solar energy systems. Finally, some local taxing districts allow property tax exemptions for the value of solar energy systems. Because tax laws change frequently, it is best to check with your state or local taxing agency, or with a local supplier of solar equipment, for the latest information.

\section{Electricity for a modern home}

\section{When the Chases mozed to their PV-powered home} in the wilds of southwest Florida, they were able to bring along all of their electrical appliances.

\section{Then Joyce and George Chase discovered it would cost $\$ 15,000$ to extend a utility line to their new home on the} Peace River in southwest Florida, they decided instead to use a stand-alone PV system to power their appliances and lights. George, whose weekend cabin on the same site had been powered by a stand-alone PV system and battery, designed the house from scratch with the cooperation of the local building inspector.

Today, a visitor to this modern $185-\mathrm{m}^{2}\left(2000-\mathrm{ft}^{2}\right)$ home would never guess there is no utility power. All fixtures, outlets, and electrical appliances are standard. Although most of the Chases' appliances operate on dc, an inverter converts some of their dc power stored in batteries to ac for those that require ac power. Gcorge put the battery and control rooms in a central spot that shortened the length of wire needed, keeping costs down and increasing efficiency. Based on advice from the inspector, George installed larger-gauge wire for the dc circuits. Today, the Chases have all the conveniences of the city, from a hair dryer and a microwave oven, to a clothes washer, TV, and ceiling fans.

The PV system has operated without a problem since 1988, and is maintained with little effort. George says that he could easily forget to check on the system because there are no moving parts to squeak, grind, or use fuel. But every month he checks the water level and chemistry of the batteries. Twice a year he changes the tilt angle on the roof-mounted PV modules-a nearly flat angle for summer when the sun is high, and a steeper angle for winter when the sun is lower in the sky. If prolonged cloudy weather blocks the sun, George runs a battery charger he rigged up to his tractor for a few hours and keeps the battery bank charged.
This home in Florida has been completely powered since 1988 by roof-mounted PV modules rated at 658 watts. The system charges eight batteries, supplies dc laads, and uses a 2000-watt inverter to supply ac loads -including clothes washer. microwave, and TV. The house is buit 3 meters above the ground to withstand flooding of the Peace River. (Photos: George Chase)

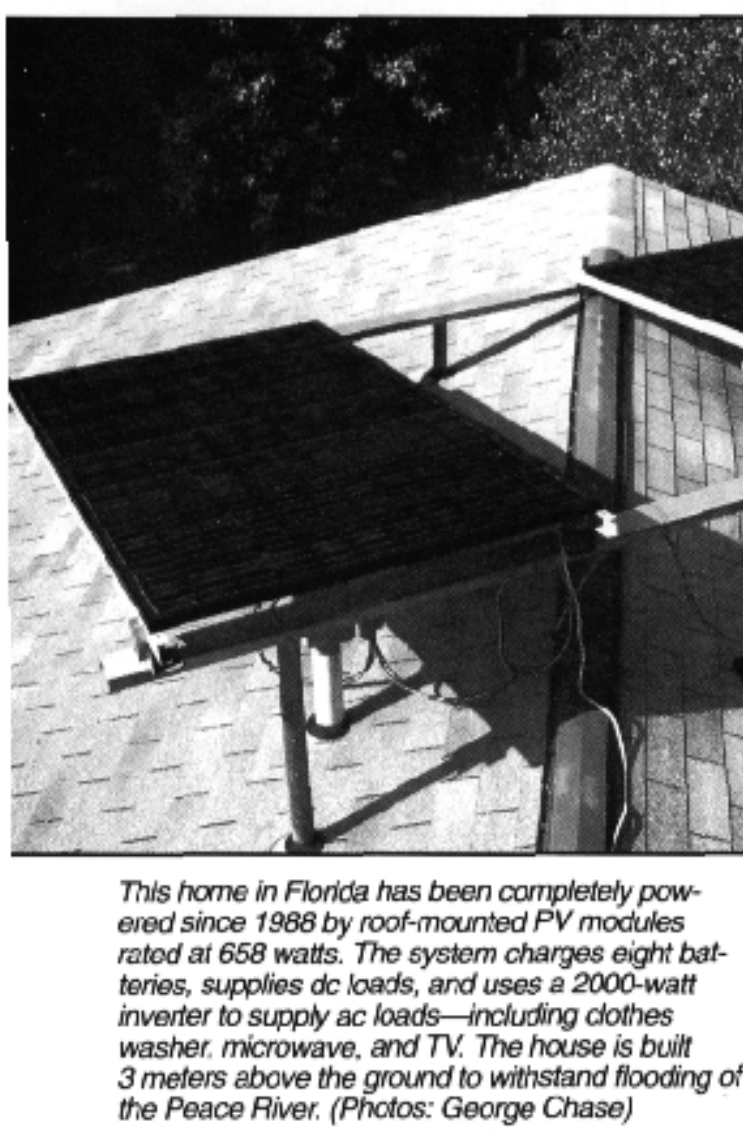


Joyce says she likes the simplicity of the system. "The photovoltaic modules produce more than enough power for our needs, without gauges and switches all over the place. Our home is proof that you can use solar energy and not sacrifice modern convenience or beauty."

\section{Electricity for railroad signals}

The Chessie System Railway chose PV as a power source for a remote signal in West Virginia because of its reliability.

ignals that control the operation of trains are crucial to the safe and efficient use of railroad tracks, and the power source for these signals must be completely reliable. Where utility power is available, signals have a bank of rechargeable batteries to draw from, in case the utility line goes down. Where it

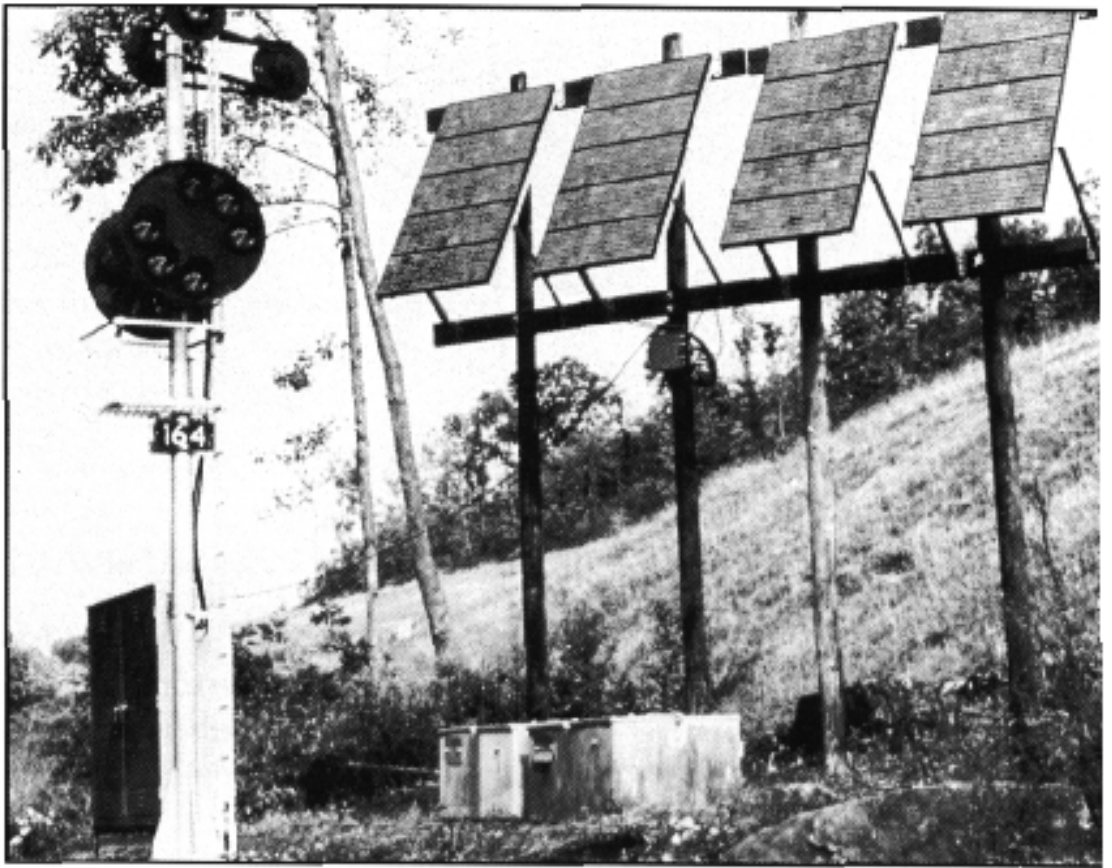
would be too costly to bring in a power line, primary batteries need to be replaced every 6 to 18 months, depending on railway traffic. By the mid-1980s, the cost to dispose of the used primary batteries was becoming greater than their original purchase price, so railroads were looking for another way to power signals far from utility lines.

In 1985, the Chessie System Railway (now CSX Transportation) needed a power source for a large new signal in a remote part of West Virginia. Because the power line was too far away, and the relatively large power load imposed by the signal would be difficult to serve with primary batteries, the train control department at Chessie decided on a PV system and rechargeable batteries.

\section{Applications of PV Systems With Batteries*}

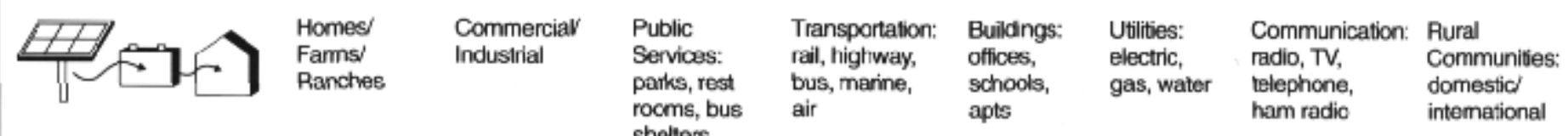

\begin{tabular}{|c|c|c|c|c|c|c|c|c|}
\hline $\begin{array}{l}\text { Indoor or outdoor } \\
\text { lighting }\end{array}$ & $\bullet$ & $\bullet$ & $\bullet$ & $\bullet$ & - & $\bullet$ & $\bullet$ & $\bullet$ \\
\hline $\begin{array}{l}\text { Waming signs, } \\
\text { lights, sirens }\end{array}$ & $\bullet$ & $\bullet$ & $\bullet$ & $\bullet$ & $\bullet$ & $\bullet$ & $\bullet$ & \\
\hline $\begin{array}{l}\text { Monikoring: water, air, temp. } \\
\text { flow, seismic, motion }\end{array}$ & $\bullet$ & $\bullet$ & - & $\bullet$ & $\bullet$ & $\bullet$ & $\bullet$ & \\
\hline $\begin{array}{l}\text { Vehicle battery } \\
\text { charging }\end{array}$ & $\bullet$ & $\bullet$ & - & - & & $\bullet$ & & $\bullet$ \\
\hline $\begin{array}{l}\text { Cathodic protection } \\
\text { against comosion }\end{array}$ & & $\bullet$ & $\bullet$ & - & $\bullet$ & - & & \\
\hline $\begin{array}{l}\text { Switches: electric, valves, } \\
\text { gate openers }\end{array}$ & $\bullet$ & $\bullet$ & $\bullet$ & $\bullet$ & $\bullet$ & $\bullet$ & $\bullet$ & \\
\hline $\begin{array}{l}\text { Remote power: radio, } \\
\text { telephone, telemetry }\end{array}$ & $\bullet$ & & $\bullet$ & $\bullet$ & & - & $\bullet$ & - \\
\hline Oi and fuel pumping & $\bullet$ & $\bullet$ & $\bullet$ & $\bullet$ & & $\bullet$ & & \\
\hline Refrigeration & $\bullet$ & $\bullet$ & & & $\bullet$ & & & $\bullet$ \\
\hline
\end{tabular}


How much does

$P V$-generated

electricity cost?

There is no simple answer.

Many small PV systems

designed to power a few

fluorescent lights and a small

TV are much cheaper than

the next best alternatives-

running a new power line,

replacing and disposing of

primary batteries (those

batteries that are used once

and then disposed of, such as

flashlight batteries), or using

an engine generator.

The cost of electricity from

larger systems, those able, for

example, to power a modern

home, is evaluated according

to the cost per kilowatt hour

(kWh). The cost depends on

the initial cost, interest on

the loan (for paying the initial

cost), the cost of system

maintenance, the expected

lifetime of the system, and

how much electricity it

produces. Using typical

borrowing costs and

equipment life, the cost of

PV-generated energy in

1993 ranged from $\$ 0.20$ to

s0.50/kWh.
Railway engineers sized the PV array and battery bank for a "worst case" weather scenario--20 days without sunlight. To aid in the system sizing, a computer program simulated the site conditions, including weather, sunlight, and signal usage. The engineers also incorporated especially rugged components to discourage vandals. The PV arrays are supported on sturdy aluminum frames designed to mount on the standard wooden poles and crossbeams used by the railroad. The modules have protective back plates and enclosed wiring connections. In addition, the batteries are housed in a concrete bunker, which protects them from vandalism and from weather.

The PV-powered signal has operated reliably sinœ 1985 . Railway personnel check out the PV installation twice a year, and, according to the installer, the rechargeable batteries are expected to last 10 years or longer.

The railroad has now installed more than $75 \mathrm{PV}$ systems, and CSX Transportation routinely considers PV along with other power options for new signals. Furthermore, the company regularly upgrades old primary batteries with PV-powered, rechargeable systems to save money. 


\section{PV with Generators}

Working together, $P V$ and other electric generators can meet more varied demands for electricity, conveniently and for a lower cost than either can meet alone.

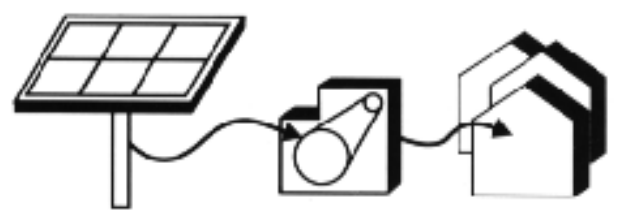

W hen power must always be available or when larger amounts of electricity than a PV system alone can supply are occasionally needed, an electric generator can work effectively with a PV system to supply the load. During the daytime, the PV modules quietly supply daytime energy needs and charge batteries. If the batteries run low, the engine-generator runs at full power-its most cost- and fuelefficient mode of operation-until they are charged. And in some systems the generator makes up the difference when electrical demand exceeds the combined output of the PV modules and the batteries.

Systems using several types of electrical generation combine the advantages of each. Engine-generators can produce electricity any time. Thus, they provide an excellent backup for the PV modules - which produce power only during daylight hours-when power is needed at night or on cloudy days. On the other hand, PV operates quietly and inexpensively, and does not pollute. Using PV and generators together can also reduce the initial cost of the system. If no other form of generation is available, the PV array and the battery storage must be large enough to supply nighttime electrical needs. However, having an engine-generator as "backup" means fewer PV modules and batteries are necessary to supply power whenever it is needed.

Including generators makes designing PV systems more complex, but they are still easy to operate. In fact, modern electronic controllers allow such systems to operate automatically. Controllers can be set to automatically switch generators or to supply ac or dc loads or some of each. In addition to engine generators, electricity from wind generators, small hydro plants, and any other source of electrical energy can be added to make a larger hybrid power system.

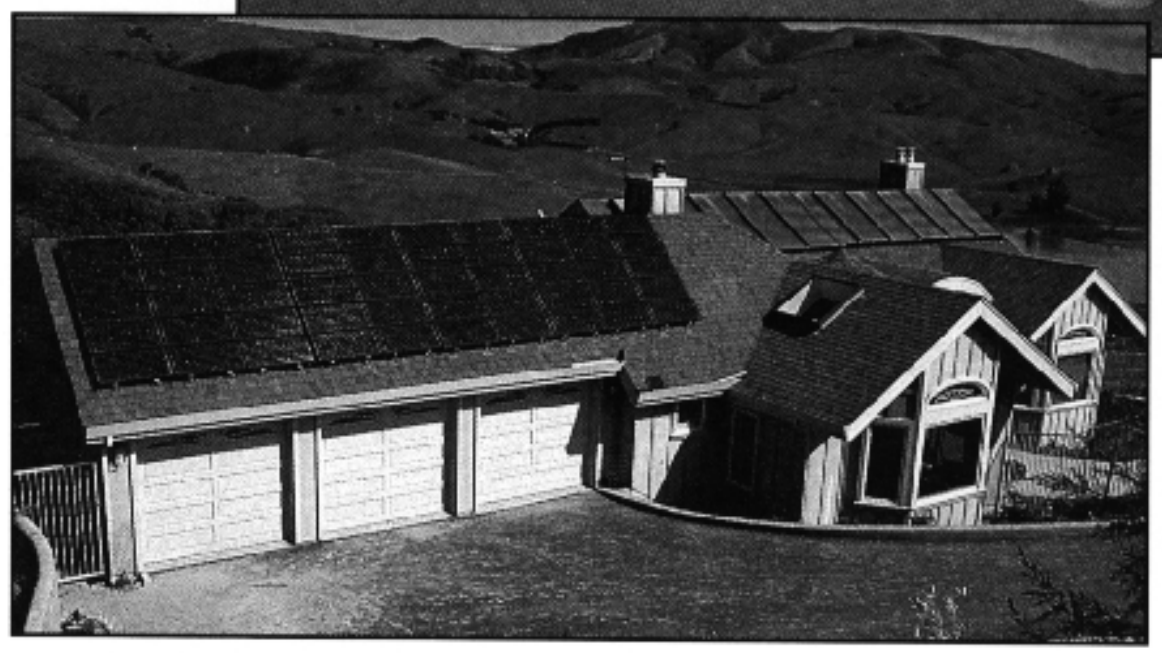

A portable PV/propane hybrid system (center) provides electricity for the Callomia State University Desert Research Center (top) in southern Cakfomia. The facility, which is far from utility power lines, includes a commercial kitchen, machine shop, classrooms, laboratory, and domitories that sieep 75 pecple. (Photos: Northem Power Systems)

This modem home in San Rafael, California (bottom), operates independently of the utility system. (Photo: Solar Depot) 


\section{Electricity for a telephone signal booster}

At a remote signal station in the mountains of northern Neuada, Sprint Communications decided to reduce the runtime on its propane-powered electric generators by adding PV modules.

W

Then Sprint Communications built its east-west fiber-optic cable line in the late $1980 \mathrm{~s}$, it needed a regenerator station every $35 \mathrm{~km} \mathrm{(22} \mathrm{mi)} \mathrm{to} \mathrm{boost} \mathrm{the}$ signal. These regenerator stations use electricity 24 hours a day, 7 days a week to power the transmission equipment and to control shelter temperatures. Utility power serves most of the stations, which have 2 hours of backup battery capacity should the power line go down.

But at Sand Pass, Nevada, 2 hours north of Reno, bringing in utility power was prohibitively expensive. When Sprint built a regenerator station there in 1986, it installed two propane-powered electric generators, or "gensets." To maintain the gen-sets a mechanic drove out to the pass every month, and to provide fuel, a teamster hauled a heavy propane tank over rough dirt roads to the site every 3 months.

Concerned with reducing these maintenance expenses, Rich Coakley, a network engineer at Sprint Communications, read an article describing PVpowered telecommunications sites in Peru. Like Sand Pass, these sites operated unattended and the PV systems kept the battery banks charged in a hostile environment. Coakley set out to have a PV system installed at the Sand Pass station.

Installation took less than a day. The equipment arrived, preassembled and securely packed, in a refurbished metal shipping container-the kind used to hold goods traveling on container ships and flatbed trucks. The container now serves as the support structure and equipment shelter at the site.

The PV array and propane gen-sets at Sand Pass complement each other. The PV array charges batteries that power the dc transmission equipment. The gen-sets run to power the ac motor in the air-conditioning unit only when the shelter thermostat calls for air conditioning. As added backup, the gen-sets can charge the batteries if necessary. Relieving the gen-sets of their everyday battery-charging duties has also reduced runtime. Thus, the PV system has significantly lowered fuel and maintenance costs for the station.

At Sand Pass in Nevada, 72 PV modules (each 60 watts) (bottom), two propanepowered generators, and a large battery bank (top) operate together to improve the economics and reliability of a remote telephone signal booster station. (Photo: Northern Power Systems)

12 Tapping Into the Sun 


\section{Electricity for a village power system}

For 25 years the village of Xcalak, in Mexico, had struggled to keep diesel generators running. Then the village decided to provide itself with a more reliable source of electric power by connecting PV modules to the generating system.

$T$ he people of Xcalak, a remote village on the east coast of the Yucatan peninsula, wanted to replace their diesel generators because it was expensive to ship fuel to the village and because the generators kept breaking down. Located $110 \mathrm{~km}(68 \mathrm{mi})$ from the nearest utility line, this village of 350 could not convince the utility to spend \$3.2 million for a line extension. But when the villagers turned to their government, a bold new solution emerged-add solar electric modules and wind generators to the existing diesel system to make a large hybrid electrical generating system.

For Xcalak, the hybrid system offered many advantages. Construction costs would be a fraction of those required for a line extension, and fuel and maintenance expenses for the hybrid system would be lower than for running the diesels alone. The system itself would have greater generating capacity, thus providing more homes and businesses with electric power. And the hybrid system would be more reliable than diesel generators operating alone because it includes multiple backup generation and a larger battery bank. The villagers would get what they had been demanding for 25 years - reliable electricity 24 hours a day.

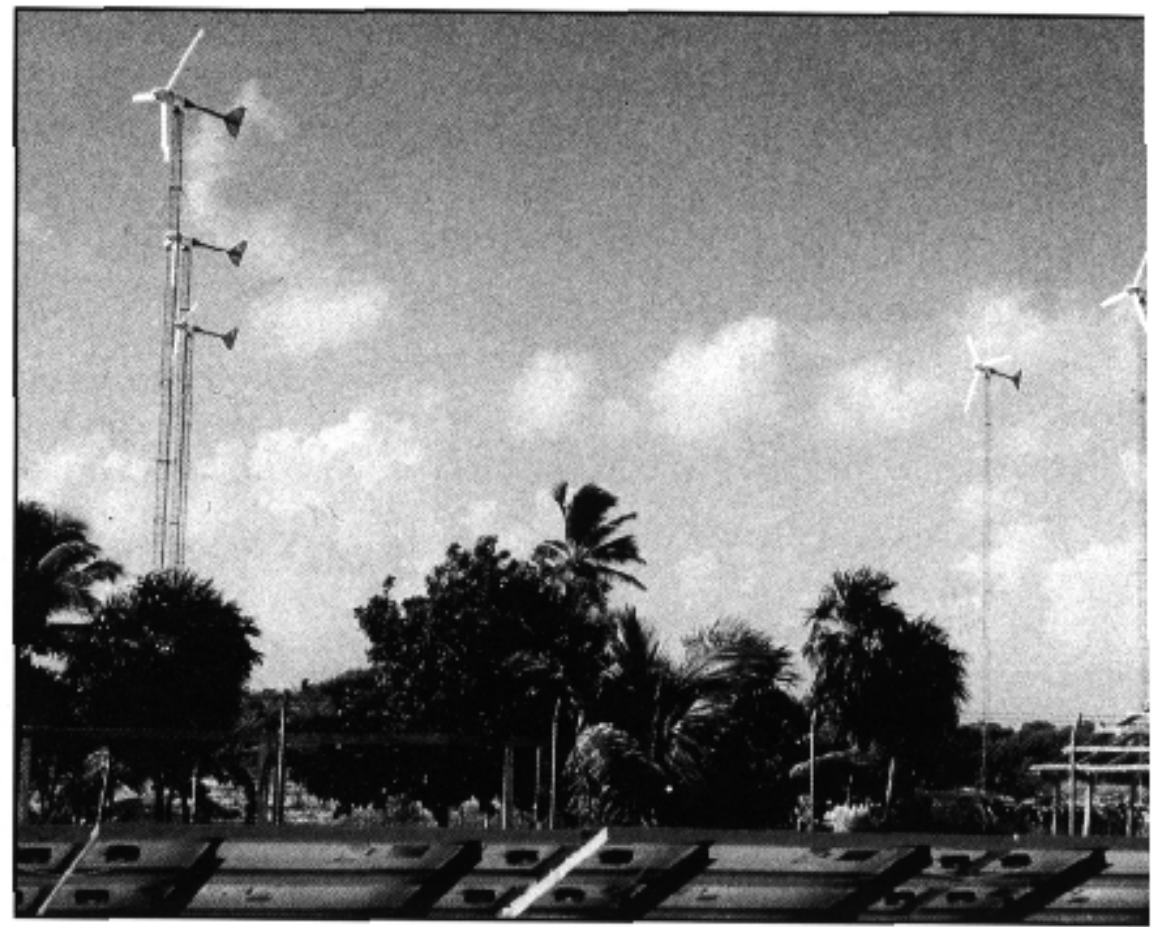

In the village of Xcalak, Mexico, PV is part of the largest hybrid generation system in the Americas. The system includes six wind turbines, $234 \mathrm{PV}$ modules, 36 batteries, a $40-k W$ inverter to convert power to ac, a diesel generator, and a sophisticated control systern. As electrical energy needs increase, the system can be expanded. (Photo: Bergey Windpower, Inc.)

\begin{tabular}{l}
\multicolumn{70}{c|}{$\begin{array}{l}\text { Applications of PV Systems With Additional Generators* } \\
\text { Remote living: villages, } \\
\text { resorts, research stations }\end{array}$} \\
$\begin{array}{l}\text { Backup for ossential } \\
\text { services: medical, computer, } \\
\text { refrigeration }\end{array}$ \\
$\begin{array}{l}\text { Pemote operations: signal } \\
\text { boosters, relay stations }\end{array}$
\end{tabular}


How much space

does PV take?

The most common modules

(using cells made from

crystalline silicon) generate

100 to 120 watts per square

meter $\left(\mathrm{W} / \mathrm{m}^{2}\right)$ (per 10 square

feet $\left[\mathrm{ft}^{2}\right]$ ). Thus, one (square

meter) module generates

enough electricity to power a

100-W light bulb. At the other

end of the range, a PV power

plant laid out on a square

piece of land measuring

approximately $160 \mathrm{~km}$ (100 mi)

on a side could supply all of

the electricity consumed

annually by the entire United

States.
The generation system was installed in 1992 with the support of the national government of Mexico, the local utility, and the village of Xcalak. The state of Quintana Roo and the national government of Mexico paid for the initial cost of the project. The utility updated and expanded the village wiring system to accommodate increased generating capacity. The village pays for system operation and maintenance.

Xcalak's hybrid electric system uses PV, wind turbines, and diesel to generate power. Batteries store electric energy produced by the PV and wind turbines for use 24 hours a day. An inverter converts the dc from the batteries to the ac provided to village residents. The PV arrays generate electricity during the day, and the wind turbines charge batteries whenever the wind blows. (The winds are usually best at night.) If the batteries become drained after a series of cloudy, windless days, or if the demand for electricity increases, the village can choose to run the diesel generator.

In remote villages the world over, providing reliable electric power can improve the economy and the quality of life for village residents. For Xcalak, adding renewable energy generators to their diesel system lowered operating costs and increased the reliability of electric service. When the hybrid system went on-line in 1992, it powered 80 homes, four restaurants, and one 20-room hotel. The village tourist industry centers around the hotel and restaurants, and its fishing industry benefits from reliable refrigeration - all without being connected to the central utility grid. 


\section{Grid-Connected PV}

Where utility power is available, a grid-connected PV system can supply some of the energy needed and use the utility in place of batteries.

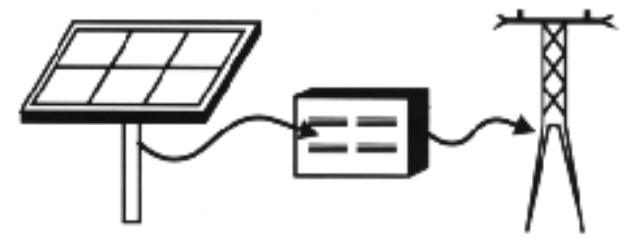

ome homeowners, considered pioneers in the energy field, are using PV

systems connected to the utility grid. They are doing so because they like

that the system reduces the amount of electricity they purchase from the utility each month. They also like the fact that PV consumes no fuel and generates no pollution.

The owner of a grid-connected PV system buys and sells electricity each month. Electricity generated by the PV system is either used on site or fed through a meter into the utility grid. When a home or business requires more electricity than the PV array is generating, for example, in the evening, the need is automatically met by power from the utility grid. When the home or business requires less electricity than the PV array is generating, the excess is fed (or "sold") back to the utility. Used this way, the utility "backs up" the PV like batteries do in stand-alone systems. At the end of the month a credit for electricity sold gets deducted from charges for electricity purchased.

Utilities are required to buy power from owners of PV systems (and other independent producers of electricity) under the Public Utilities Regulatory Policy Act of 1978 (PURPA). An approved, utilitygrade inverter converts the dc power from PV modules into ac power that exactly matches the voltage and frequency of the electricity flowing in the utility line, and also meets the utility's safety and power quality requirements. Safety switches in the inverter automatically disconnect the PV system from the line if utility power fails. This safety disconnect protects utility repair personnel from being shocked by electricity flowing from the PV array into what they would expect to be a "dead" utility line.

In addition to cooperating under PURPA, utilities are establishing rate structures that may make PV grid-connected systems more economical. (At today's prices, when the cost of installing a utility-connected PV system is divided by the amount of electricity it will produce over 30 years, PVgenerated electricity is almost always more expensive than power supplied by the utility.) For

Nantucket Elementary School (top) uses this gridconnected PV system to supplement the power it uses from the local utility. (Photo: Jack Weinberg for Ascension Technoiogy)

This electric vehicle recharging station in south Florida (bottom) is powered by a gridconnected PV array mounted on the roof. When no vehicles need recharging, power from the madules is transferred to the utility line. (Photo: University of South Florida)

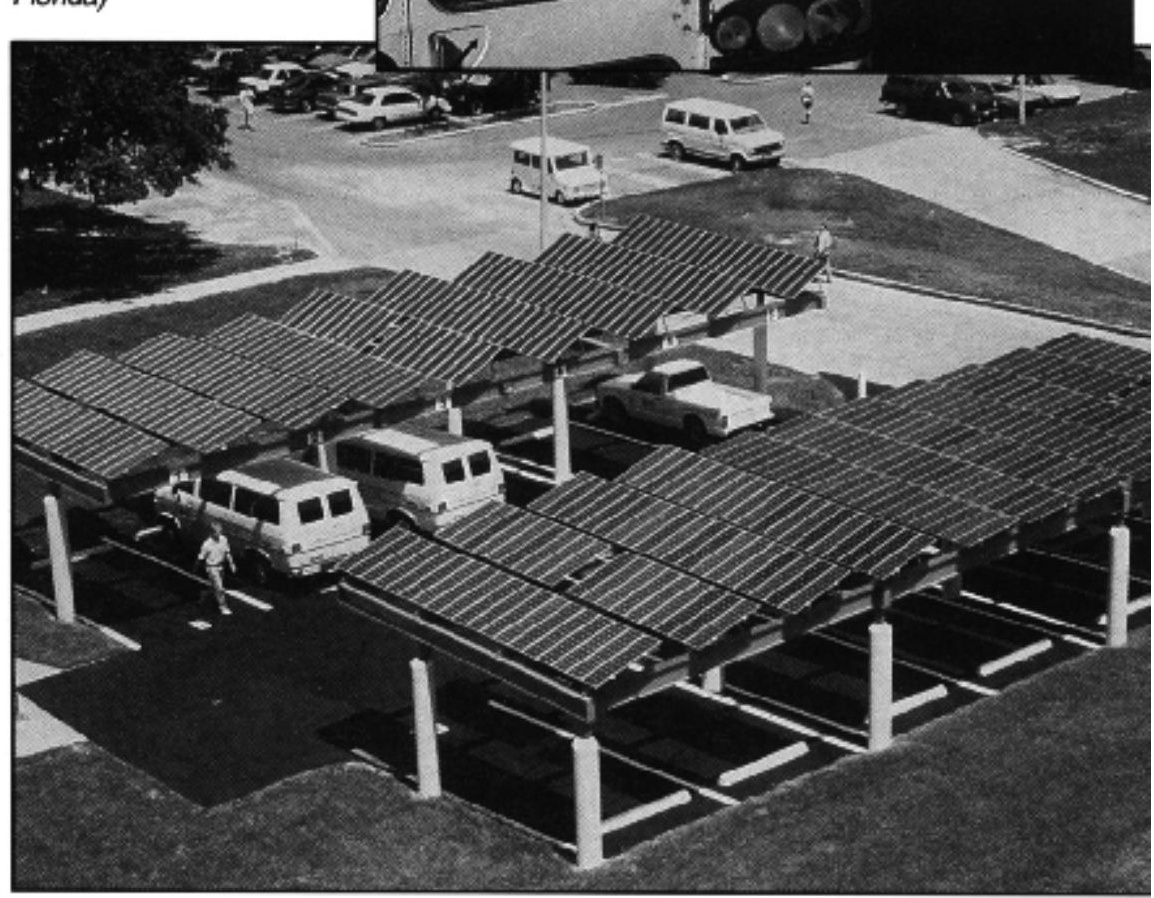


Do PV systems work

in cold and cloudy

weather?

PV systems produce power in

all types of weather. On partly

cloudy days they can produce

up to $80 \%$ of their potential

energy delivery; on hazy/

humid days, about $50 \%$; and

on extremely overcast days,

they still produce up to $30 \%$.

This grid-connected, PV-powered home in Massachusents has been operating without problems since 1980. Under a net billing arrangement with their electric utility, Bosion Edison Company, the owners of this 4.5-kW PV array sell excess electricity in the summer that nearly balances the backup energy they buy in winter. (Photo: Solar Design Associates)

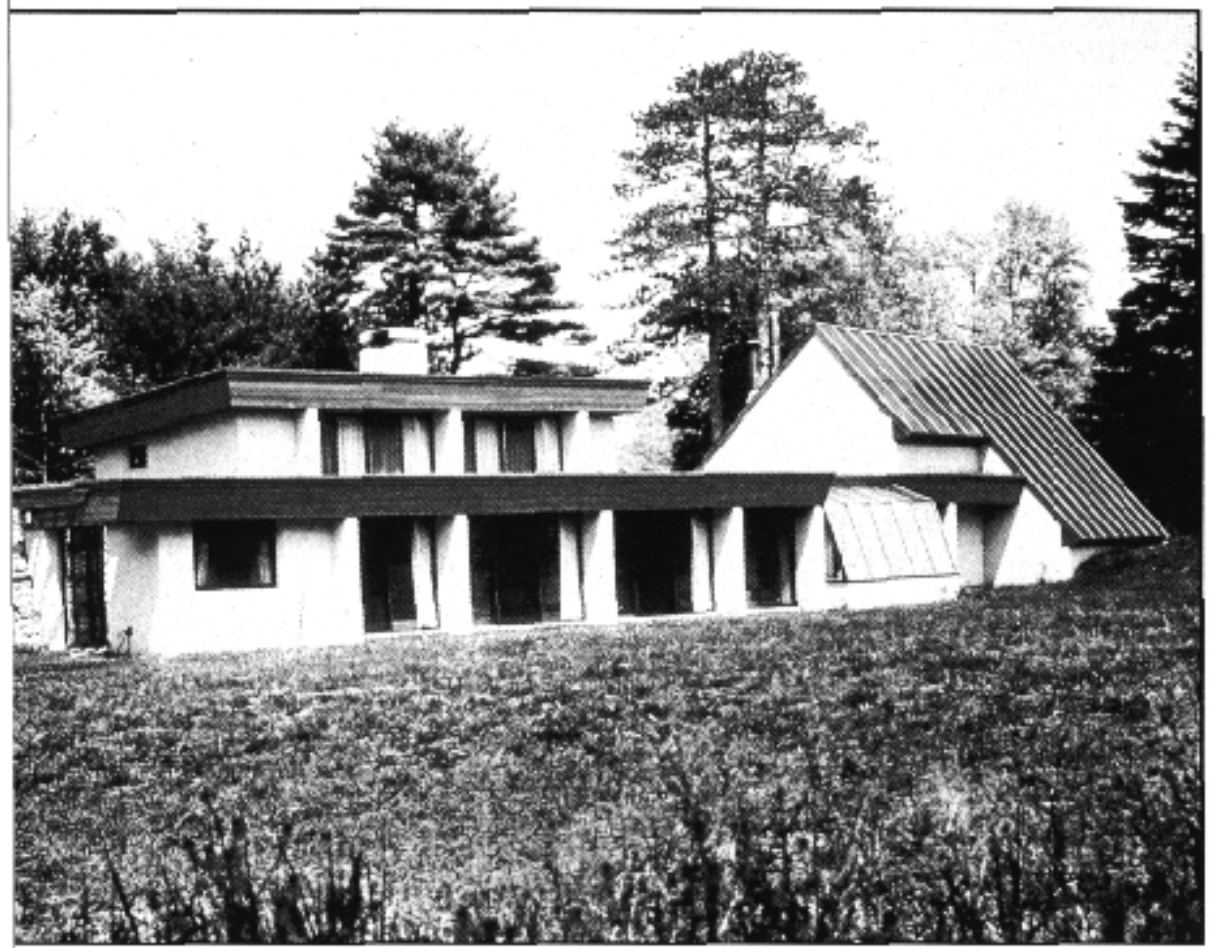

example, some utilities charge higher prices at certain times of the day. In some parts of the country, the highest charges for electricity under this time-of-day pricing structure are now nearly equal to the cost of energy from PV. The better the match between the electrical output of the PV modules and the time of highest prices, the more effective the system will be in reducing utility bills.

\section{Electricity for an energy-efficient home}

\author{
A retired couple in Massachusetts, concerned about the \\ environment and rising energy costs, chose utility-connected PV \\ to power their energy-efficient home.
}

retired couple in southeastern Massachusetts commissioned the design of a PV-powered, all-solar home because they were concerned about the envimonment and wanted to be self-reliant. They did not want to maintain a battery bank at their home and utility power was available, so they specified a utility-connected photovoltaic system.

The privately financed home, completed in 1980, incorporates many energy-conserving features. Built largely of masonry, concrete, and steel with earth berms against the north, east, and west sides, it stays warm in winter and cool in summer. The south wall of the house is nearly all glass to soak up the winter sun and the overhang of the roof provides shade to the south-facing glass in the summer. A solar thermal water heater takes care of all the owners' hot water needs and also helps heat the house.

The photovoltaic system generates most of the electricity the couple needs. The PV modules occupy $40 \mathrm{~m}^{2}\left(430 \mathrm{ft}^{2}\right)$ of the south-facing roof. The $\mathrm{dc}$ electricity from the modules passes through an inverter for conversion to utilitygrade ac power. Most of this electricity is used in the home and the excess is sold to the utility.

The homeowners have what is called a "net-metering" arrangement with their electric utility. The home has a standard electric meter that spins forward when the house is drawing electricity from the utility and backward when the PV system is feeding excess electricity into the grid. At the end of the month, they pay for any net forward movement of the meter, or get a credit if there was net backward motion.

Ever since the system was installed in 1980 , the owners have found that the home is nearly energy self-sufficient over the calendar year. During the summer months, the PV system generates more electricity than the house uses. The surplus power spins their electric meter backward as PV-generated electricity passes out into the grid. In the winter, the house uses more electricity than the PV system produces, so some power flows in from the utility grid. 
The homeowners are modest in their electricity use, yet they operate a refrigerator/freezer, electric clothes dryer, and electric oven, along with lighting, power tools, TV, stereo, and various small appliances. The integration of photovoltaics with energy-conscious design allows them to live lightly on the earth in a comfortable home.

\title{
Electricity for demand-side management
}

\author{
In Albany, New York, Niagara Mohawk Power Corporation is \\ exploring how a grid-connected PV system can help even out \\ a building's electrical demand.
}

\begin{abstract}
E power plants to supply demand for just a few hours a day. Peaking power plants are usually the most expensive for a utility to operate. In addition, the utility's electric distribution system has to be sized to handle these high, short-term loads.
\end{abstract} lectric utilities must have the capability to supply power to all their customers. During certain times-such as hot afternoons when many air conditioners are running-demand is particularly high. These "peak demand" spikes are costly to serve because the utility must fire up "peaking"

Utilities have tried various ways to smooth out electrical demand, including demand-side management (DSM). Utility DSM tools include encouraging energy conservation, charging higher rates during peak demand times, and charging higher rates (demand charges) to those who have all their appliances turned on at once.

Installing grid-connected photovoltaic arrays on rooftops may become a good utility DSM tool. The PVgenerated electricity is used directly to help supply a building's peak demand, which often nearly coincides with times when the sun is shining the brightest. For example, most summer-peaking utilities experience the highest demand on their systems because of air conditioning loads on hot, sunny days. These are the same days the output of PV systems is also high.

To evaluate PV for DSM, Niagara Mohawk Power Corporation and the Empire State Electric Energy Research Corporation installed a PV system in 1990 on an energy-efficient office building in Albany, New York. The array is an experimental system and is considerably smaller than the one that would be needed to completely offset this building's peak demand. Nevertheless, the system's output, although a small part of the building's total demand, corresponds to the time when the peaks in demand occur.

The Albany system is thus demonstrating PV's potential to help utilities reduce peak demand. It has been operating as designed, with no major problems. Because afternoon clouds were reducing the PV system's effect on peak demand somewhat, the Niagara Mohawk project team added batteries to the system. The batteries store electricity to help reduce peak demand on cloudy afternoons. The continued study of this system will shed further light on the benefits of PV for DSM for utilities and their customers.

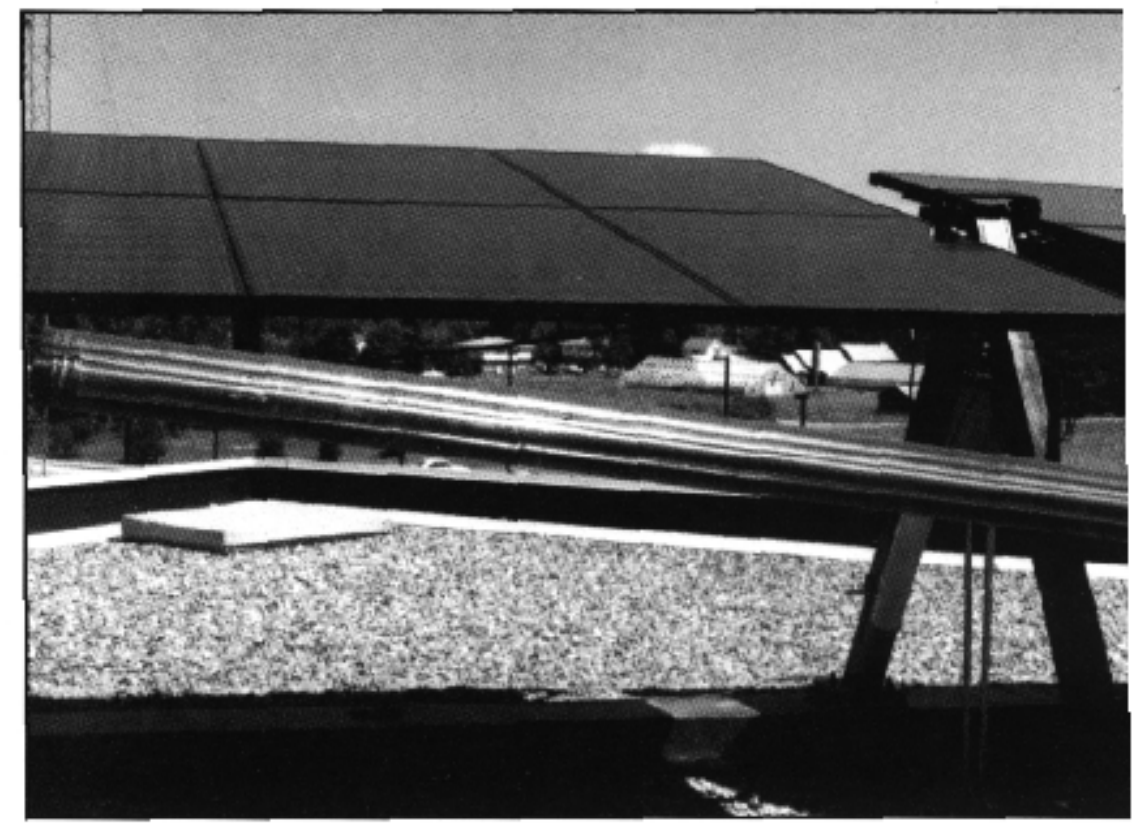

The PV system on this office building helps supply the building's electrical needs during the utility's peak dermand times. Uthities are studying the value of this approach for evening out demand over the day. (Photo: Northem Power Systems) 
lines and servicing area. Installing PV systems near other utility distribution equipment such as substations can also relieve overloading of the equipment in the substation.

Electric, gas, and water utilities have been using small PV systems economically for several years. Most of these systems are less than $1 \mathrm{~kW}$ and use batteries for energy storage. These systems are performing many jobs for utilities, from powering aircraft warning beacons on transmission towers to monitoring air quality of fluid flows. They have demonstrated the reliability and durability of PV for utility applications and are paving the way for larger systems to be added in the future.

\section{Electricity for a utility substation}

\section{Pacific Gas $\mathcal{E}$ Electric Company (PGSE) needed more capacity on hot afternoons at its Kerman substation in the San Joaquin Valley, California. PGEE installed a PV electric generating system at Kerman instead of replacing the substation.}

Dacific Gas and Electric Company's Kerman substation, near Fresno, 1 California, was becoming overloaded on hot summer days. This is the time when air conditioning and water pumping needs are at their greatest and the utility experiences its peak demand. Overloading heats up substation components, which shortens the life of expensive transformers, reduces power quality for customers, and increases line losses during transmission. Analysts in PG\&E's research group argued that a PV array could meet the extra demand at Kerman, because it occurred on days when the solar cells would be producing well.

The analysts at PG\&E believed using PV to "support" a substation during peaks in electrical demand might make economic sense for their utility, but no one knew quantitatively how much the PV grid support would be worth. Because upgrading the Kerman substation would cost several million dollars, PG\&E-as part of the PVUSA project-decided to install a PV system as a research project to evaluate the benefits of grid support.

The PV system installed at Kerman in 1993 produces the most power on sunny summer afternoons, when PG\&E experiences its peak demand and when electricity has the highest value to the utility. The PV system maintains its electrical output close to its rated capacity with the PV modules mounted on trackers that change the tilt of the modules as the sun moves across the sky during this critical period.

The Kerman substation experiment is designed to measure the value to the utility of a $500-\mathrm{kW}$ generating plant that can be quickly (within 6 months) placed where extra power is needed. Monitors record clectrical output throughout the day and provide detailed information on system output. The results of this experiment will be widely distributed among utilities across the country.

\section{Do PV arrays follow} the sun?

Some do while others are mounted at fixed angles. For large-scale energy production, output is noticeably affected by the movement of the sun across the sky during the day. For example, at the Sacramento Municipal Utility District PV plant in California, computercontrolled motors move the solar panels slightly every 12 minutes for about 6 hours in the middle of the day. Tracking the sun this way produces about $30 \%$ more energy than if the modules were fixed. In general, the extra energy captured by following the sun must be weighed against the costs of installing and maintaining the tracking system.

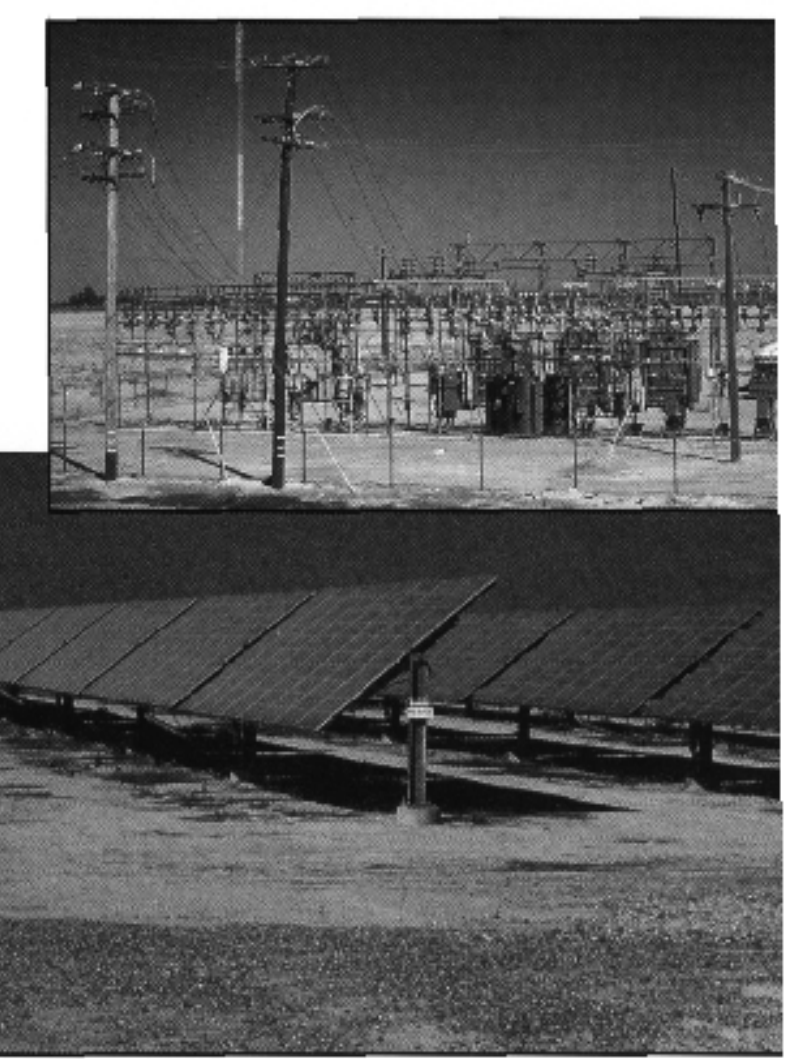

PG\&E's Kerman substation, in Califomia, uses the electrical production of this $500-k W$ PV system to help meet peak demand on sunny summer afternoons. Researchers are measuring the value to the utility of this arrangement, hoping to demonstrate another use for PV in utility transmission and distribution systems. (Photo: Roger Taylor, National Ronewable Energy Laboratory) 


\title{
Electricity Now and in the Future
}

\author{
Each year solar electric generating systems offer people more \\ solutions to their energy problems.
}
A PV technology continues to improve, it steadily moves into new and larger markets. PV systems have been the best choice for many jobs since the first commercial PV cells were developed.

For example, PV cells have been the exclusive power source for satellites orbiting the earth since the $1960 \mathrm{~s}$. PV systems have been used for remote standalone systems throughout the world since the 1970s. In the 1980s, commercial and consumer product manufacturers began incorporating PV into everything from watches and calculators to music boxes. And in the

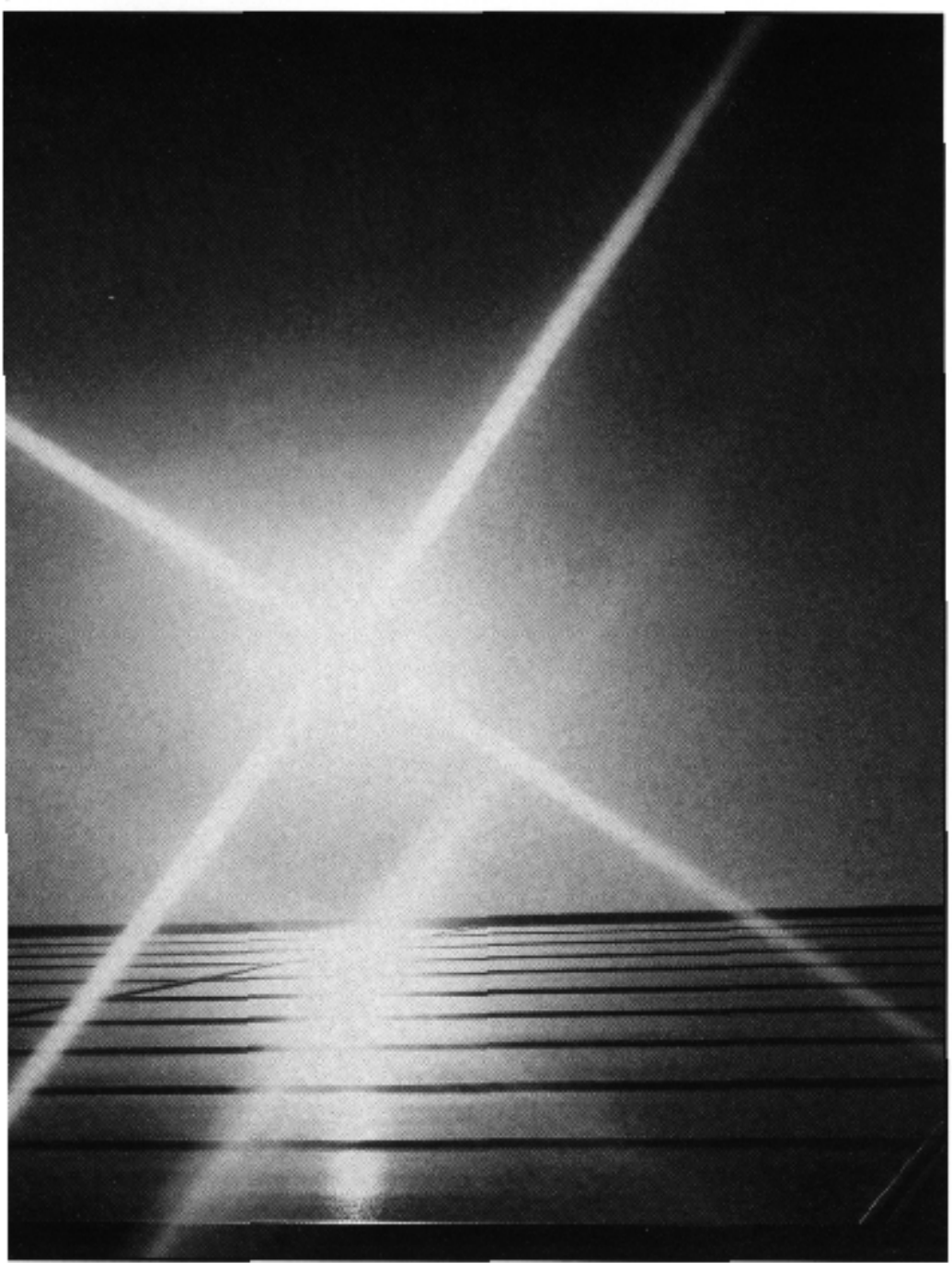
$1990 \mathrm{~s}$, many utilities are finding PV to be the best choice for thousands of small power needs. During the next decade, a large part of the world's population will be introduced to electricity produced by PV systems. These PV systems will make the traditional requirements of building large, expensive power plants and distribution systems unnecessary.

As the costs of PV continue to decline and as PV technology continues to improve, several potentially huge markets for PV will open up. For example, building materials that incorporate PV cells will be designed right into new high rises and homes, helping to ventilate and light the buildings. Consumer products ranging from battery-powered hand tools to automobiles will take advantage of electricityproducing components containing PV materials. Meanwhile, electric utilities will find more and more ways to use PV to supply the needs of their customers.

The summer sun previews a prototype PV' system that could reflect the way utilities use large numbers of PV systems in the tuture. Pictured here (and on the front cover), this 500-kW PV system is connected to PG\&E's Kerman substation, where it reduces the load on that utility's distribution lines and equipment connected to the substation. (Photo: Terry M. O'Rourke) 


\section{For More Information}

\section{Books, Reports, and Journals}

Home Power: The Hands-on Ioumal of Home-made Power. Ashland, OR: Home Power, Inc.

Photozoltaics for Municipal Planners. (April 1993). NREL/TP-411-5450.

DE93000099. Golden, CO: National Renewable Energy Laboratory.

Risser, V. (April 1988). Stand-alone Photowoltaic Systems: A Hundbook of Recommended Design Practices. SAND87-7023. Albuquerque, NM: Sandia National Laboratories.

Solar Today. Boulder, CO: The American Solar Energy Society.

Stokes, K. (April 1993). Photowoltaic Power as a Utility Service: Guidelines for Livestack Water Pumping. SAND93-7043. Albuquerque, NM: Sandia National Laboratories.

Strong, S.J. (1987). The Solar Electric House: A Design Manual for Home-scale Photozoltaic Power Systems. Emmaus, PA: Rodale Press.

Thomas, M.G. (1989). Photovoltaic Systems for Gonernment Agencies. SAND88-3149. Albuquerque, NM: Sandia National Laboratories.

Zweibel, K. (1990). Harnessing Solar Power: The Photovoltaics Challenge. New York and London: Plenum Press.

\section{Organizations}

\section{For general questions:}

U.S. Department of Energy

Energy Efficiency and Renewable

Energy Clearinghouse (EREC)

P.O. Box 3048

Merrifield, VA 22116

800-363-3732

\section{For technical questions:}

Technical Inquiry Service

National Renewable Energy

Laboratory

1617 Cole Blvd.

Golden, CO 80401

303-275-4099

Design Assistance Center

Sandia National Laboratories

Division 6223

Albuquerque, NM 87185

505-844-3698

\section{For information on suppliers:}

The Solar Energy Industries

Association

777 North Capitol St, N.E.

Suite 805

Washington, DC 20002

202-408-0660

\section{For information on utility}

involvement:

Dr. Edgar DeMeo

Manager, Solar Power Program

Electric Power Research Institute

3412 Hillview Ave.

Palo Alto, CA 94303

415-855-2159 
Produced for the

\section{U.S. Department of Energy}

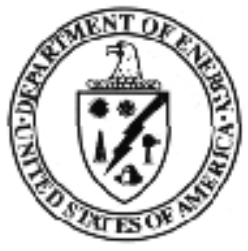

1000 independence Avenue, SW

Washington, DC 20585

by the National Renewable Energy Laboratory, a DOE national laboratory.

\section{DOE/CH10093-203-Rev.1}

DE93000075

Revised April 1995

NOTCE: This repcrt was prepared as an account of work sponsored by an agency of the Urited States govermment. Neither the United States govemment nor any agency thereof, nor ary of their empoyoes, makes any warranty, express or implied, or assumes any legal liability or responsibility for the accuracy, completeness, or usefulness of any information, apparatus, product, cr process

disclosed, or represents that its use would not infringe privately owned rights. Relerence herein to any specific commercial product, process, or service by trade name, trademark, manufacturer, or otherwise does not necessarily constitute or imply its endorsement, recommendation, or favoring by the United States govemment or any agency thereof. The views and opinions cf authors expressed herein do not necessarly state or refect those of the United States government or any agency thereof.

Printed in the United States of America

Available to DOE and DOE contractors from:

Office of Scentific and Technical Information (OSTI)

P.O. Box 62

Oak Ridge, TN 37831

Prices available by calling (615) 576-8401

Available from:

National Techrical Information Service

U.S. Depariment of Commerce

5285 Port Royal Roed

Springfield, VA 22161

(703) $487-4650$

Information pertaining to the pricting cades can be found in the current issue of the following publications which are generally available in most librarics: Govemment Reports Announcements and Index (GRA and n; Scientific and Technical Abstract Reports (STAR), and publication NTIS-PR-360 available from NTIS at the above address. 